\title{
Study of behavior alloy Ti and 316L in to simulated body fluid by electrochemical techniques
}

\author{
Daniela Garcés López ${ }^{1}$, Pedro José Arango ${ }^{1}$, \\ Alejandro Echavarria ${ }^{2}$, Belarmino Segura Giraldo ${ }^{1}$, \\ Elisabeth Restrepo Parra ${ }^{1}$
}

\author{
${ }^{1}$ Universidad Nacional de Colombia Sede Manizales, Laboratorio de Física del Plasma, Km. 9 vía al aeropuerto, Campus \\ La Nubia, Manizales, Caldas, Colombia \\ ${ }^{2}$ Corrosion and Protection Group, University of Antioquia, 62 Street No. 52-59, Medellín, Santa Fé, Colombia \\ e-mail: dgarces1@unal.edu.co
}

\begin{abstract}
In this work, Ti-316L stainless steel was produced, and its electrochemical behavior was characterized. Tisteel alloys were produced using an induction furnace, by mixing commercial Ti and 316L stainless steel. Xray diffraction analyses showed the presence of both the materials, Ti and 316L, in the samples produced. The elemental composition of the materials was determined by optical emission spectroscopy and energydispersive spectroscopy, which showed similar quantities of both the elements. Both commercial 316L stainless steel and Ti-steel were studied in simulated biological fluid for imitate a like composition of body blood plasma. Electrochemical experiments conducted at $37^{\circ} \mathrm{C}$ indicated the stable passive polarization behavior of the Ti-steel alloy. Furthermore, the electrochemical behavior of the $316 \mathrm{~L}$ stainless steel was also analyzed for comparison purposes. Corrosion velocities were determined using the Tafel method and corrosion resistances were obtained using the electrochemical impedance spectroscopy. The Ti-steel exhibited better protection capacity, compared with the commercial $316 \mathrm{~L}$ steel. The corrosion velocity and the passive current density of the Ti-steel alloy were lower than those exhibited by the 316L stainless steel.
\end{abstract}

Keywords: XRD, elemental composition, Tafel curves, corrosion velocity.

\section{INTRODUCTION}

Currently, biomaterials play an important role in the improvement of human life quality [1, 2]. For biomedical implants, metallic biomaterials have been widely used in surgical procedures such as replacement of bone joints and dental implants. Although the materials technology has increased the performance and longevity of the implants, materials employed in these implants still exhibit lack of efficiencies, regarding the biological compatibility and the mechanical performance. Because of the advances in the study of $\mathrm{Ti}$ compounds, it is expected that this material can play an important role in the development of a new generation of medical implants [3, 4].

The need to seek new materials for medical implants has developed to avoid the drawbacks of the currently used materials. Although metallic biomaterials have been widely used for biomedical implants because of their mechanical resistance and capacity of deformation, they exhibit the disadvantage of low corrosion resistance [5]. For this reason, it was found that a great number of metals and alloys are not useful for biomedical implants because they are highly reactive when they are placed into the human body. Therefore, in general, metals used for biomedical implants are made of austenitic stainless steels, cobaltchrome-based alloys, and titanium and its alloys [6, 7]. Ti is considered one of the most promising materials for the new generation of biomedical implants because of its low elasticity modulus (two times lower than that of stainless steel and Co-Cr alloys), decreased stress shielding, and decreased osseous reabsorption [8][10]. Furthermore, because of the high biocompatibility of $\mathrm{Ti}$, it has become striking for implantation applications [11]-[13]. The chemical biocompatibility of Ti is largely because of its high corrosion resistance, as it avoids the release of cations to the physiological environment. This protection is given by the $\mathrm{TiO}_{2}$ layer formed naturally on the surface of $\mathrm{Ti}[14,15]$. Several studies have been conducted regarding Ti implants. Echavarría et al. [16] used electrochemical impedance spectroscopy for evaluating the behavior of commercially pure $\mathrm{Ti}$ that was used in dental implants. They concluded that $\mathrm{Ti}$ exhibit a similar biocompatible behavior as that of stainless steel. Yong Li et. al [17] produced coatings of zinc-reinforced Ti 
nanotubes on Ti substrates, using the anodization and hydrothermal treatment methods. The produced materials exhibited a better osseous formation that improves the osteointegration between the bone and the implant; moreover, they inhibited bacterial growth.

In this work, a study of the corrosion resistance of Ti-reinforced 316L stainless steel in simulated biological fluid (SBF) was performed. An induction furnace was used to produce the alloy. Chemical, morphological, and electrochemical analyses were performed using the Electrochemical Impedance Spectroscopy and Tafel curves. Although several studies of the biocompatible behavior of the stainless steel can be found in the literature, it is necessary to deepen and widen the knowledge about the biocompatibility of steels when they are combined with other elements as titanium, to improve their anticorrosive properties and osteointegration in living beings.

\section{EXPERIMENTAL DETAILS}

Ti-steel alloys were produced using an induction furnace Fornax® T 200-240 VAC, 50/60 Hz, where the 316L stainless steel mixed with Ti was melted in a crucible by applying an alternating current. Figure 1 shows the schematic representation of the production process of Ti-steel. The synthetization was performed by introducing steel and Ti into the crucible; then, an external magnetic field was applied. This magnetic field induced an a.c. current that melts and mixes the materials. Table 1 presents the parameters used for materials processing.

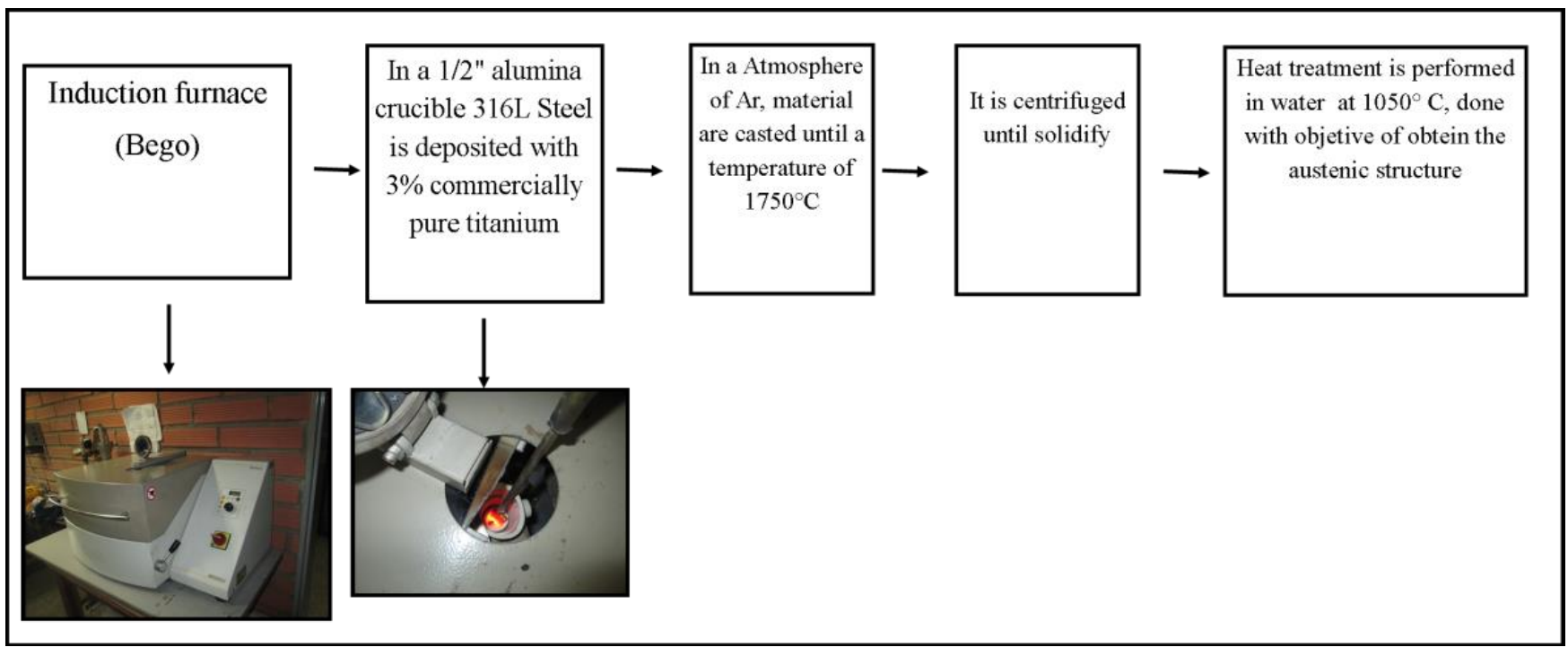

Figure 1: Schematic representation of Ti-steel alloy production using an induction furnace

Table 1: Parameters for the Ti-steel alloy production using an induction furnace.

\begin{tabular}{c|c}
\hline PARAMETER & DESCRIPTION \\
\hline Environment & Argon \\
\hline Velocity of rotation & $4000 \mathrm{rpm}$ (revolutions per minute) \\
\hline Frequency & $25 \mathrm{kHz}$ \\
\hline Melting temperature & 1730 \\
\hline
\end{tabular}

The chemical composition was analyzed using an optical emission spectrometer, ARL 3460 Metal Analyzer. These analyses were performed under an argon environment, with $99.99 \%$ purity and a flux of 3.5 L/min. SEM analyses were performed using an FEI-CUANTA 250 equipment; EDX analyses were 
performed to determine the elemental composition of steel and the Ti-steel alloy; a D8 Bruker AXS Diffractometer was used for X-ray diffraction characterization. It has an X-ray source of $\mathrm{Cu} \mathrm{K} \alpha$, with $\lambda=1.5406 \AA$ and a secondary monochromator of graphite.

Electrochemical measurements were made using a potentiostat Gamry 1000 employing a cell of three electrodes, with graphite as the counter electrode and an $\mathrm{Ag} / \mathrm{AgCl}$ electrode as the reference. These measurements were performed at $37^{\circ} \mathrm{C}$, with an exposition area of $1 \mathrm{~cm}^{2}$. The tests were conducted using SBF (pH 7.4) as electrolyte. The table 2 shows the compositions and concentrations of SBF, this electrolyte was made according to the methodology established of Kokubo [18], which is used by many researchers. The critical factors for performance of the SBF are functioning in a proper temperature range, $\mathrm{pH}$ adjustment, and avoidance of precipitation. Electrochemical impedance spectroscopy (EIS) measurements were conducted with a stabilization time of $500 \mathrm{~s}$ and a frequency scan between $10^{5}$ and $0.01 \mathrm{~Hz}$. In addition, the Tafel polarization technique was performed by applying a potential of $\pm 250 \mathrm{mV}$, according to the ASTM G59-97 standard [19].

Table 2: List of reagents for the simulated biological fluid preparation and their ion concentration in the SBF and the blood plasma

\begin{tabular}{|c|c|c|c|c|}
\hline \multirow[b]{2}{*}{ No. } & \multirow[b]{2}{*}{ CHEMICAL REAGENTS } & \multirow[b]{2}{*}{ ION } & \multicolumn{2}{|c|}{ CONCENTRATION mM } \\
\hline & & & $\begin{array}{l}\text { BLOOD } \\
\text { PLASMA }\end{array}$ & SBF \\
\hline 1 & $\begin{array}{l}\text { Sodium chloride } \\
{[\mathrm{NaCl}]}\end{array}$ & $\mathrm{Na}^{+}$ & 142 & 142 \\
\hline 2 & $\begin{array}{l}\text { Sodium hydrogen carbonate } \\
{\left[\mathrm{NaHCO}_{3}\right]}\end{array}$ & $\mathrm{HCO}_{3}^{-}$ & 4,2 & 27 \\
\hline 3 & $\begin{array}{l}\text { Potassium Chloride } \\
{[\mathrm{KCl}]}\end{array}$ & $\mathrm{K}^{+}$ & 5 & 5 \\
\hline 4 & 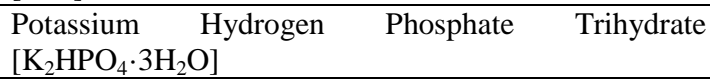 & $\mathrm{HPO}_{4}{ }^{2-}$ & 1,5 & 1,5 \\
\hline 5 & $\begin{array}{l}\text { Magnesium Chloride Hexahydrate } \\
{\left[\mathrm{MgCl}_{2} \cdot 6 \mathrm{H}_{2} \mathrm{O}\right]}\end{array}$ & $\mathrm{Mg}^{2+}$ & 2,5 & 2,5 \\
\hline 6 & Hydrogen Chloride $[\mathrm{HCl}]$ & $\mathrm{Cl}^{-}$ & 103 & 147,8 \\
\hline 7 & Calcium Chloride $\left[\mathrm{CaCl}_{2}\right]$ & $\mathrm{Ca}^{2+}$ & 27 & 4,2 \\
\hline 8 & Sodium Sulfate $\left[\mathrm{Na}_{2} \mathrm{SO}_{4}\right]$ & $\mathrm{SO}_{4}{ }^{2-}$ & 1 & 1 \\
\hline 9 & Tris(hydroxymethyl)aminomethane $\left[\left(\mathrm{HOCH}_{2}\right)_{3} \mathrm{CNH}_{2}\right]$ & Buffer & 0.5 & 0.5 \\
\hline 10 & Hydrogen Chloride [HCl] & $\mathrm{pH}$ & $7.2-7.4$ & 7.4 \\
\hline
\end{tabular}

\section{RESULTS AND DISCUSSION}

Figures 2(a) and (b) show the diffractograms of the 316L stainless steel and the commercial pure Ti, respectively. Figure 2(c) presents the diffractogram of the Ti-316L stainless steel. Table 2 presents the peaks and plains of the Ti-steel sample and intensity ratio between peaks (111)/ (110). It can be observed that the diffractogram exhibited peaks only $316 \mathrm{~L}$ austenitic steel phase. However, the change of intensities between 316L steel and Ti-steel can be observed, the calculation of intensities ratio of peaks (111)/ (110) show begin from 3.03 to 0.49 . This change is attributed of formation of titanium as solid solution in to lattice of $316 \mathrm{~L}$ steel, occupying substitutional places in cell. 


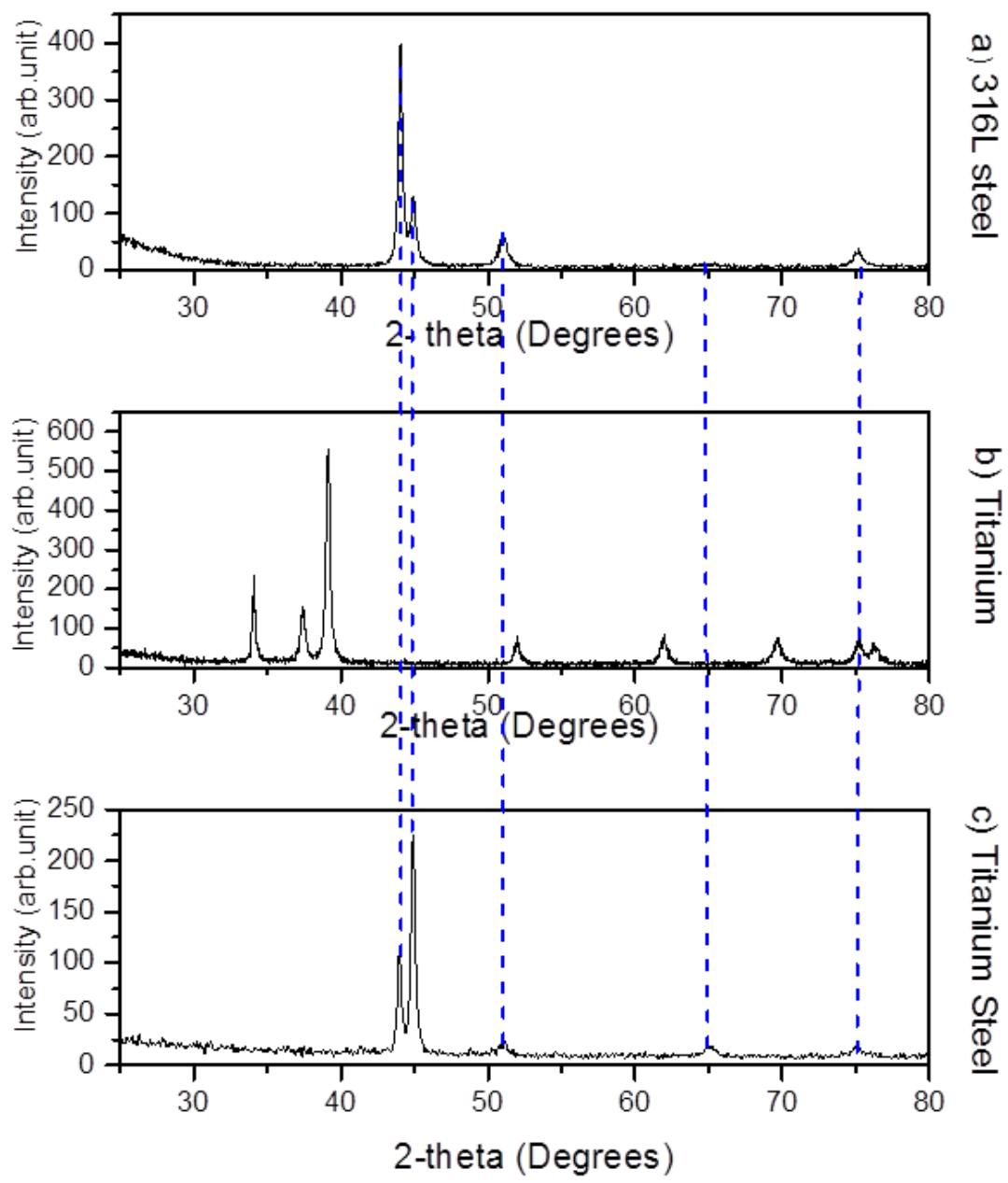

Figure 2: Diffractograms of (a) commercial 316L stainless steel, (b) commercial Ti, and (c) Ti-steel alloy

Table 3: Peaks and planes of Ti-steel alloys determined by X-ray diffraction.

\begin{tabular}{|c|c|c|c|}
\hline & MATERIAL & ANGLE & PLANE \\
\hline \multirow{6}{*}{ 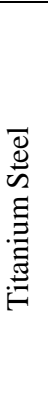 } & \multirow{5}{*}{ 316L steel } & $44.05^{\circ}$ & (111) \\
\hline & & $44.89^{\circ}$ & $(110)$ \\
\hline & & $51.05^{\circ}$ & (200) \\
\hline & & $65.23^{\circ}$ & $(220)$ \\
\hline & & 316L STEEL & TI STEEL \\
\hline & Ratio (111)/(110) & 3.03 & 0.49 \\
\hline
\end{tabular}


To analyze the chemical composition of the Ti-steel and corroborating the inclusion of $\mathrm{Ti}$ in the steel, quantitative elemental composition of the steel and Ti-steel was analyzed using optical emission spectroscopy and energy-dispersive spectroscopy (EDS). Table 4 presents the values of atomic percentages for both steel and Ti-steel, using both the techniques. The main results of this analysis were as follows: (i) the presence of $\mathrm{Ti}$ in the $\mathrm{Ti}$-steel sample, indicating the incorporation of $\mathrm{Ti}$ on the steel; (ii) the difference in the elemental composition observed by the two techniques. This difference is mainly because EDS cannot determine the presence of $\mathrm{S}, \mathrm{Nb}$, and $\mathrm{Sn}$ because of their low concentrations, considering that the instrument used in this technique has a limit of detection of $0.1 \%$. Furthermore, for the case of low-atomic number elements such as carbon and phosphor, the accuracy of the EDS technique is lower for lighter elements than that for heavier elements [20]. This could be the reason for the large difference in values of the elemental composition of these two elements obtained for the two methods.

Table 4: Elemental composition of the commercial 316L stainless steel and the Ti-steel alloy determined by optical emission spectroscopy and EDS.

\begin{tabular}{|c|c|c|c|c|}
\hline ELEMENT & $\begin{array}{l}\text { 316L STEEL } \\
\text { (SPECTROMETRY) }\end{array}$ & $\begin{array}{l}316 \mathrm{~L} \\
\text { STEEL } \\
\text { (EDS) }\end{array}$ & $\begin{array}{l}\text { TI-STEEL } \\
\text { (SPECTROMETRY) }\end{array}$ & $\begin{array}{l}\text { TI-STEEL } \\
\text { (EDS) }\end{array}$ \\
\hline$C(\%)$ & 0.030 & 1.99 & 0.04 & 1.41 \\
\hline $\operatorname{Mn}(\%)$ & 2.0 & --- & 1.74 & 2.04 \\
\hline Si (\%) & 1.0 & --- & 1.56 & 0.58 \\
\hline$S(\%)$ & 0.030 max. & --- & 0.034 & --- \\
\hline$P(\%)$ & 0.045 max. & --- & 0.056 & 0.12 \\
\hline $\operatorname{Cr}(\%)$ & $16.0-18.0$ & 15.93 & 14.67 & 20.25 \\
\hline $\mathrm{Ni}(\%)$ & $10-14$ & 11.25 & 3.69 & 8.91 \\
\hline Cu (\%) & --- & --- & 0.46 & 0.79 \\
\hline Sn (\%) & --- & --- & 0.054 & --- \\
\hline$V(\%)$ & --- & --- & 0.032 & 0.33 \\
\hline$A l(\%)$ & --- & --- & 0.12 & 0.14 \\
\hline Mo (\%) & $2.0-3.0$ & 2.04 & 0.35 & 0.33 \\
\hline$N b(\%)$ & --- & --- & 0.040 & --- \\
\hline$T i(\%)$ & --- & --- & 0.93 & 1.27 \\
\hline
\end{tabular}

Figure 3(a) shows the Nyquist diagram of the 316L steel. In this figure, two semicircles can be observed; the first one, at higher frequencies, can be attributed to the interactions between the electrolyte and the passive layer of the $316 \mathrm{~L}$ steel. This layer is responsible for protecting the steel against corrosion. Subsequently, charge transfer is inhibited due to its high resistance; however, the semicircle at lower frequencies can be due to the interactions between the electrolyte and the metal (steel).

Figure 3(b) shows the Nyquist diagram for the Ti-steel. From this figure, we can observe the semicircular tendency of the Ti-steel and an inflexion point. This semicircular tendency is attributed to the interactions between the electrolyte and the Ti-steel. The inflection point can be attributed to the diffusion that was a consequence of the interactions between the electrolyte and the electrodes, thereby causing changes in concentrations.

A comparison between Figures 3(a) and (b) showed that the Ti-steel exhibits greater resistance than the $316 \mathrm{~L}$ steel. Because the diameters semicircles represent the materials resistance, these figures indicate that the resistance of Ti-steel is in the order of $\mathrm{k} \Omega$ while that of the commercial $316 \mathrm{~L}$ steel is in the $\Omega$. 
For a better analysis of the corrosion resistance by using SBF as the electrolyte, the curves (semicircles) of both measures were fitted using equivalent circuits that represent the obtained experimental data; for performing this procedure, the Gamry Echem Analyst software as used.

a.
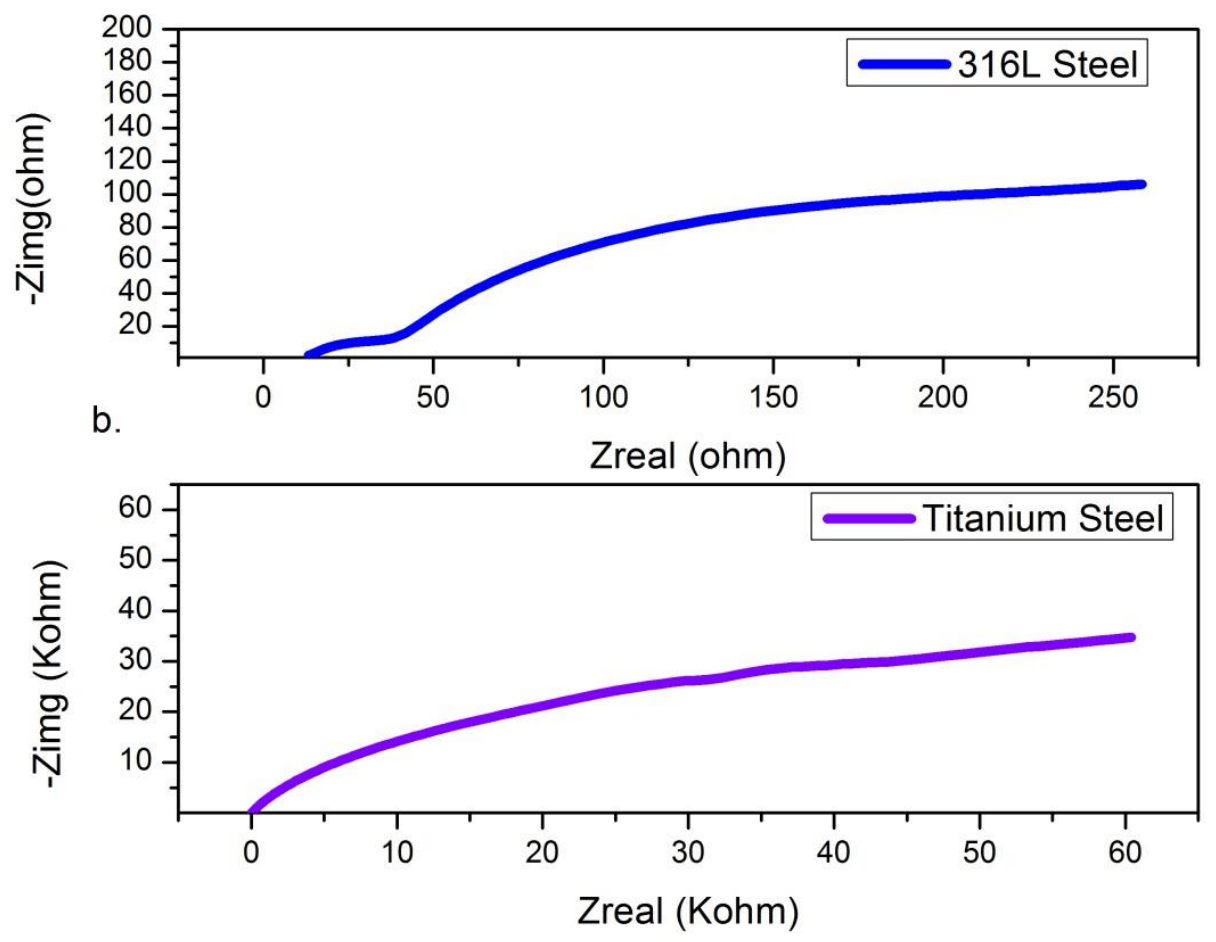

Figure 3: Nyquist diagrams of (a) commercial 316L steel and (b) Ti-steel alloy.

Figures 4(a) and (b) show the equivalent circuits that fitted the experimental data obtained, for both the 316L steel and Ti-steel. The nomenclature and description of the components are listed in Table 5. The polarization resistance (Rp) is an important parameter for determining the corrosion behavior of the materials when they are immersed in SBF. Values obtained for Rp were $57.22 \pm 0.71 \mathrm{k} \Omega$ and $103.5 \pm 3.436 \Omega$ for the Ti-steel and the $316 \mathrm{~L}$ steel, respectively. The greater resistance of Ti-steel is due to the addition of Ti to the 316L steel. This protection can be attributed to the formation of a passive layer of $\mathrm{TiO}_{2}$. The protection effect of oxide films produced in the titanium alloys is generally caused by (i) changes in the surface potential, (ii) the suppression of the activity of aggressive ion adsorption, and (iii) the decrease charge in mobility at the metal-electrolyte interface[21], [22] 


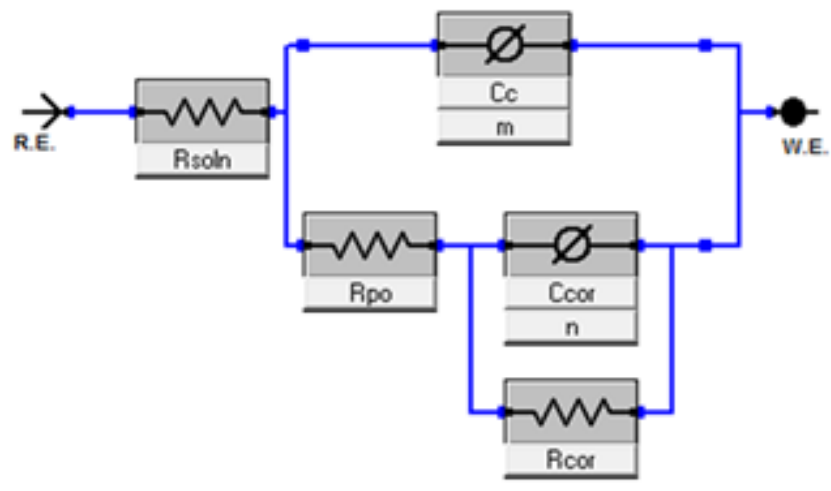

a.

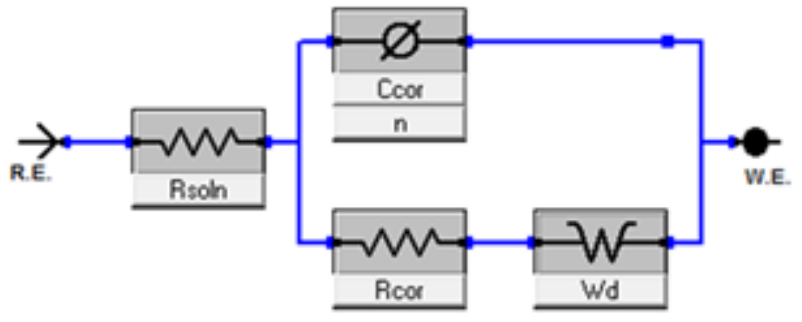

b.

Figure 4: Equivalent circuits that fit the Nyquist diagrams for (a) the 316L steel and (b) Ti-steel

Table 5: Description of the components used in the equivalent circuit for fitting the Nyquist diagram

\begin{tabular}{|c|c|}
\hline ELEMENT & REPRESENTATION \\
\hline Rsoln & Electrolyte resistance \\
\hline Rcor & $\begin{array}{l}\text { Polarization resistance or charge transfer resistance } \\
\qquad \text { in materials }\end{array}$ \\
\hline Ccor & $\begin{array}{l}\text { Charge distribution of the double layer for samples } \\
\text { that exhibit heterogeneous charge distribution. }\end{array}$ \\
\hline$W d$ & Diffusion due to the changes in concentration \\
\hline$C c$ & $\begin{array}{l}\text { Charge distribution of the double layer in the } \\
\text { passive layer }\end{array}$ \\
\hline Rpo & $\begin{array}{l}\text { Polarization resistance or charge transfer in passive } \\
\qquad \text { layer }\end{array}$ \\
\hline
\end{tabular}

The polarization Tafel curves for the 316L steel and the Ti-steel are presented in figure 5. These curves include a cathodic branch, which is represented by the most negative potential, and an anodic part, which is attributed to the most positive potential. Values of kinetic corrosion parameters such as the corrosion potential (Ecorr), corrosion current density (jcorr), and corrosion velocity were obtained from the Tafel curves. 

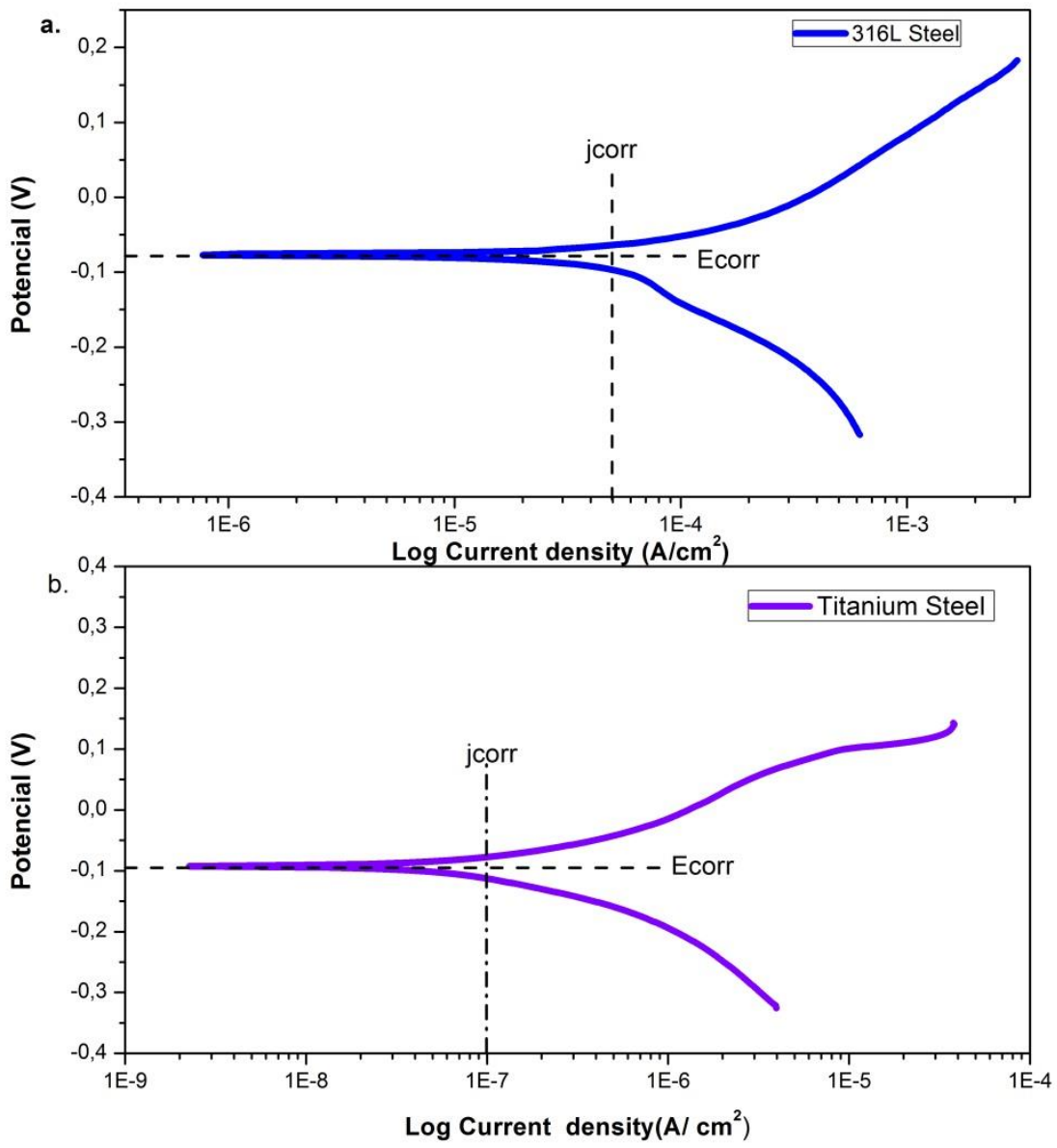

Figure 5: Polarization Tafel curves for (a) the 316L steel and (b) the Ti-steel

The corrosion parameter values obtained from the Tafel curves are summarized in Table 6. The potentiodynamic curve of the Ti-steel shifted toward lower currents, compared with that of the $316 \mathrm{~L}$ steel.

Table 6: Values of corrosion potential, corrosion current, and corrosion rate, obtained from the Tafel curves, for the commercial 316L steel and the Ti-steel

\begin{tabular}{c|c|c|c}
\hline SAMPLE & $E_{\text {corr }}(\mathbf{m V})$ & $j_{\text {corr }}\left(\mathbf{A} / \mathbf{c m}^{2}\right)$ & CORROSION RATE \\
\hline 316L steel & -77.10 & $50.10 \mu$ & $9.393 \mathrm{mpy}$ \\
\hline Ti-steel & -94.54 & $102.0 \mathrm{n}$ & $73.93 \mu \mathrm{py}$ \\
\hline
\end{tabular}

When the samples were immersed in SBF, the jcorr for the Ti-steel was lesser than the 316L steel. This behavior can be explained for the greater corrosion resistance of Ti-steel.

As mentioned earlier, this increase in the corrosion resistance of Ti-steel is attributed to the $\mathrm{TiO}_{2}$ passive layer that inhibits the absorption of corrosive ions. This passive layer also changes the surface potential and reduces the number of charge carriers in the interlayer between the metal and the electrolyte, which in turn protects the substrate from corrosion damages [22], [23].

In summary, this study clearly shows the contribution of $\mathrm{Ti}$ to the $316 \mathrm{~L}$ steel in producing a 
functional biomaterial. In addition, from the electrochemical impedance spectroscopy and polarization curves, it can be concluded that Ti-steel exhibits a better protection capacity against corrosion than the pure 316L steel.

This enhancement in the corrosion resistance behavior of Ti-steel is because the additional passive layer of $\mathrm{Ti}$ alloys overcomes the protective conditions of the passive layer formed in stainless steels [9], [24], despite both are formed because of the metal interaction with oxygen. The passive layer of Ti alloys is composed of $\mathrm{TiO}_{2}$ [21], while the passive layer of stainless steels is composed of $\mathrm{Cr}_{2} \mathrm{O}_{3}$ [23], as shown in Figure 6.

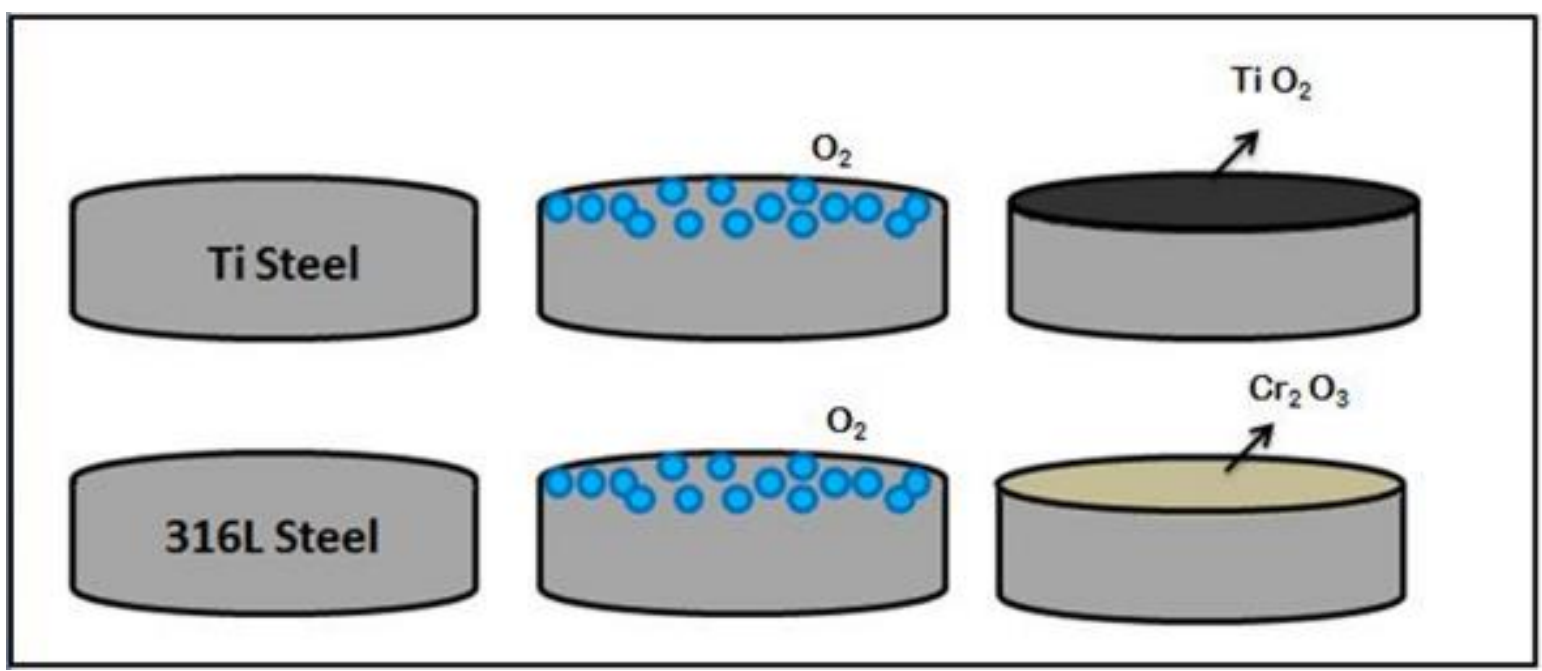

Figure 6: Passive layer formation in (a) Ti-steel and (b) 316L steel

Nevertheless, the passive layer of Ti-steel $\left(\mathrm{TiO}_{2}\right)$ is more protective than that of stainless steel $\left(\mathrm{Cr}_{2} \mathrm{O}_{3}\right)$. This behavior can be attributed to several factors. One of these factors is the valence used by each element at the time of bond formations with oxygen. Ti and $\mathrm{Cr}$ exhibit the oxidation states of +4 and +3 , respectively; these materials can be easily oxidized in the presence of water, air, or other reagents. Second, the energy required for removing four electrons (in the case of $\mathrm{Ti}^{4+}$ ) is higher than that required for removing three electrons (in the case of $\mathrm{Cr}^{3+}$ ). Third, $\mathrm{TiO}_{2}$ (Figure 7 (a)) has a covalent nature, while $\mathrm{Cr}_{2} \mathrm{O}_{3}($ Figure 7(b)) has an ionic nature, which results in stronger and less reactive bonds in $\mathrm{TiO}_{2}[26]$.

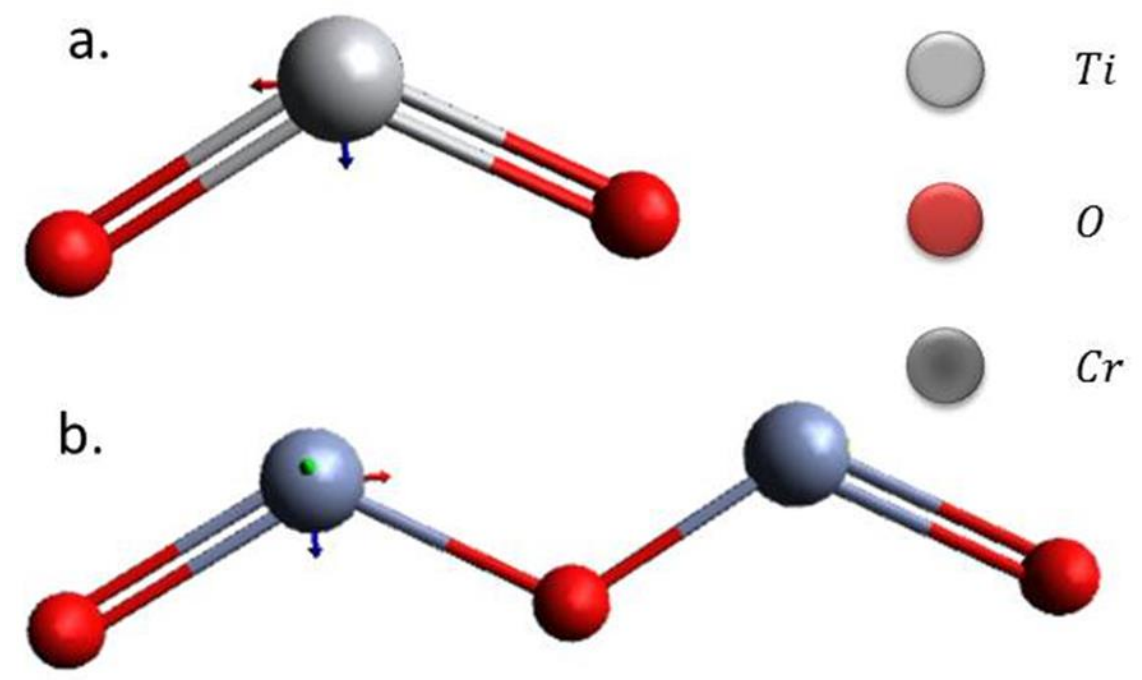

Figure 7: Schematic representation of a (a) $\mathrm{TiO}_{2}$ molecule and (b) $\mathrm{Cr}_{2} \mathrm{O}_{3}$ molecule 


\section{CONCLUSIONS}

- Ti-steel alloy was produced using an induction furnace. The structural, morphological, and electrochemical behaviors of the alloy were characterized by comparing their properties with those of the commercial 316L stainless steel.

- Using X-ray diffraction, peaks of the 316L stainless steel and Ti were found in Ti-steel, with possible overlapping of some peaks in both the materials.

- Optical emission spectrometry and EDS were used for determining the elemental composition of both the 316L steel and the Ti-steel, corroborating the presence of Ti in the samples produced.

- The electrochemical characterization of both the 316L steel and the Ti-steel were performed using EIS and Tafel polarization curves; these results showed that the Ti-steel exhibited better protection capacity, compared with the commercial 316L steel.

- The corrosion resistance and corrosion velocity in SBF of both the samples was obtained from EIS and Tafel, and it was observed that the Ti-steel alloys exhibit higher corrosion resistance and lower corrosion velocity.

\section{ACKNOWLEDGMENTS}

The authors gratefully acknowledge financial support from the Dirección Nacional de Investigaciones of the National University.

\section{BIBLIOGRAPHY}

[1] OKAZAKI, Y., RAO, S., TATEISHI, T., et al., "Cytocompatibility of various metal and development of new titanium alloys for medical implants", Materials Science and Engineering: A., v. 243, n.1-2, pp. 250256, Mar. 1998. http://www.sciencedirect.com/science/article/pii/S0921509397008095

[2] MAHYUDIN, F., WIDHIYANTO, L., HERMAWAN, H., "Biomaterials in orthopedics", In: Advanced Structured Materials. , v. 58, Biomaterials and Medical Devices., Springer, Cham, pp. 161-181, 2016. https://link.springer.com/chapter/10.1007/978-3-319-14845-8_7

[3] MISHNAEVSKY L., et al., "Nanostructured titanium-based materials for medical implants : Modeling and development", Materials Science and Engineering: R., v. 81, pp. 1-19, Jul. 2014. http://www.sciencedirect.com/science/article/pii/S0927796X14000515

[4] STATHI, K., TARANTILI, P., POLYZOIS, G., "The effect of accelerated ageing on performance properties of addition type silicone biomaterials", Materials Science: Materials in Medicine, v. 21, n. 5, pp. 1403-1411, Jan. 2010. https://link.springer.com/article/10.1007/s10856-010-3991-y

[5] CHENG, Z., LIAN, J., HUI Y., et al., "Biocompatible DCPD coating formed on az91d magnesium alloy by chemical deposition and its corrosion behaviors in SBF", Journal Bionic Engineering, v. 11, n. 4, pp. 610-619,Oct. 2014. http://www.sciencedirect.com/science/article/pii/S167265291460072X

[6] KOHN,D. H., "Metals in medical applications", Current Opinion in Solid State and Materials Science , v. 3, n. 3, pp. 309-316, Jun. 1998. http://www.sciencedirect.com/science/article/pii/S1359028698801071

[7] GOTMAN, I., “Characteristics of Metals Used in Implants”, Journal Endourology, v. 11, n. 6, pp. 383389, Mar.1997. http://online.liebertpub.com/doi/pdf/10.1089/end.1997.11.383

[8] DAVIS, J., et al., "Handbook of Materials for Medical Devices," Ohio, ASM Internacional, 2003. http://www.asminternational.org/documents/10192/1849770/06974G_Frontmatter.pdf

[9] GIL, F., PLANELL, J., “Aplicaciones biomédicas del titanio v sus aleaciones,” Biomecánica, v.1, n.1, pp. 34-42, Dec.1993. https://upcommons.upc.edu/bitstream/handle/2099/6814/Article04.pdf

[10] NIINOMI, M., NAKAI, M., HIEDA, J., "Development of new metallic alloys for biomedical applications", Acta Biomaterialia, v. 8, n. 11. pp. 3888-3903, Nov. 2012. http://www.sciencedirect.com/science/article/pii/S1742706112002942

[11] LI, Y., YANG, C., ZHAO, H., et al., "New developments of ti-based alloys for biomedical applications", Materials, v. 7, n. 3. pp. 1709-1800, Mar. 2014. http://www.mdpi.com/19961944/7/3/1709/htm 
[12] GEETHA, M., SINGH, A. K., ASOKAMANI R., et al., "Ti based biomaterials, the ultimate choice for orthopedic implants - A review", Progress in Materials Science, v. 54, n. 3. pp. 397-425, May. 2009. http://www.sciencedirect.com/science/article/pii/S0079642508001126

[13] YETIM, T., "Corrosion Behavior of Ag-doped TiO2 Coatings on Commercially Pure Titanium in Simulated Body Fluid Solution", Journal Bionic Engineering, v. 13, n.3, pp. 397-405, Jul. 2016. http://www.sciencedirect.com/science/article/pii/S1672652916603116

[14] PAN, J., THIERRY, D., LEYGRAF, C., "Electrochemical impedance spectroscopy study of the passive oxide film on titanium for implant application”, Electrochimica Acta, v. 41, n. 7-8, pp. 1143-1153, May. 1996. http://www.sciencedirect.com/science/article/pii/0013468695004653

[15] CZARNOWSKA, E., WIERZCHOŃ, T., MARANDA-NIEDBAŁA, A., "Properties of the surface layers on titanium alloy and their biocompatibility in in vitro tests," Journal of Materials Processing

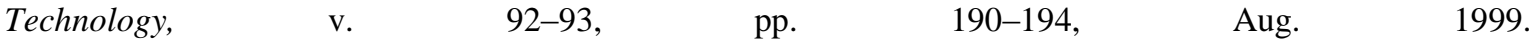
http://www.sciencedirect.com/science/article/pii/S0924013699002289

[16] ECHAVARRIA, A. I., ARROYAVE, C. E., "Electrochemical assesment of some titanium and stainless steel implant dental alloys," Revista Metalurgia, v.39, pp. 174-181, Sep.2003.http://revistademetalurgia.revistas.csic.es/index.php/revistademetalurgia/article/view/1116/1128

[17] LI, Y., et al., "Enhanced osseointegration and antibacterial action of zinc-loaded titania-nanotube-coated titanium substrates: In vitro and in vivo studies," Journal of Biomedical Materials Research Part A, v. 102, n. 11, pp. 3939-3950, Dec. 2014. http://onlinelibrary.wiley.com/doi/10.1002/jbm.a.35060/full

[18] KOKUBO, T., TAKADAMA, H., "How useful is SBF in predicting in vivo bone bioactivity," $\begin{array}{lllllll}\text { Biomaterials, } & \text { v. } & 27, & \text { n. } & 15, & \text { pp. } & 2907-2915,\end{array}$ http://www.sciencedirect.com/science/article/pii/S0142961206000457

[19] ASTM G59-97, "Standard Test Method for Conducting Potentiodynamic Polarization Resistance Measurements”, ASTM International, West Conshohocken, PA, 1991

https://www.astm.org/DATABASE.CART/HISTORICAL/G59-97.htm

[20] CICILEO, G., GASSA, L., et al., "Corrosión de aleaciones de aluminio de aplicación aeroespacial", Congreso Internacional de Ciencia y Tecnología de Metalurgia y Materiales 2013, Puerto Iguazú, Argentina, Aug.

2013.

https://www.researchgate.net/profile/Gabriela_Cicileo/publication/273121214_CORROSION_DE_ALEACI ONES_DE_ALUMINIO_DE_APLICACION_AEROESPACIAL/links/54f73ce20cf2ccffe9daf365.pdf

[21] WANG, Y., YU, H., CHEN, C., et al., "Review of the biocompatibility of micro-arc oxidation coated titanium alloys," Materials and Design, v. 85, pp. 640-652, Nov. 2015. http://www.sciencedirect.com/science/article/pii/S0264127515301611

[22] YEROKHIN. A. L., NIE, X., LEYLAND, A., et al., "Characterization of oxide films produced by plasma electrolytic oxidation of a Ti-6Al-4V alloy," Surface and Coatings Technology, v. 130, n. 2-3, pp. 195-206, Aug. 2000. http://www.sciencedirect.com/science/article/pii/S0257897200007192

[23] SHOKOUHFAR, M., DEHGHANIAN C., MONTAZERI, M., et al., "Preparation of ceramic coating on Ti substrate by plasma electrolytic oxidation in different electrolytes and evaluation of its corrosion resistance: Part II," Applied Surface Science, v. 258, n. 7, pp. 2416-2423, Jan. 2012. http://www.sciencedirect.com/science/article/pii/S0169433211016333

[24] MANERO, J., et al., "Wear behavior of the pair Ti-6Al-4V-UHMWPE of acrylic bone cements containing different radiopaque agents", Journal of Biomaterials Applications, v. 18, n. 4, pp. 305-319, Apr. 2004. http://journals.sagepub.com/doi/abs/10.1177/0885328204041531

[25] RECLARU, L., LERF, R., ESCHLER, Y., et al., "Corrosion behavior of a welded stainless-steel orthopedic implant," Biomaterials, v. 22, n. 3, pp. 269-279, Feb. 2001. http://www.sciencedirect.com/science/article/pii/S014296120000185X

[26] COTTON, A., WILKINSON, G., Advanced Inorganic Chemistry, 4 Ed., New York, John Wiley \& Sons, 1980.http://web.uni-plovdiv.bg/plamenpenchev/mag/books/inorgchem/Cotton-Wilkinson\%20-

\%20Advanced\%20Inorganic\%20Chemistry_file1.pdf 


\section{ORCID}

Daniela Garcés López

https://orcid.org/0000-0002-9444-2082

Pedro José Arango

https://orcid.org/0000-0002-8629-5035

Alejandro Echavarria

https://orcid.org/0000-0002-1858-365X

Belarmino Segura Giraldo

https://orcid.org/0000-0001-9205-8573

Elisabeth Restrepo Parra

https://orcid.org/0000-0002-1734-1173 